\title{
Political Efficacy and Participation in Twenty-Seven Democracies: How Electoral Systems Shape Political Behaviour
}

\author{
JEFFREY A. KARP AND SUSAN A. BANDUCCI*
}

\begin{abstract}
Advocates of proportional representation (PR) often cite its potential for increasing citizen involvement in politics as one of PR's fundamental advantages over plurality or first-past-the-post systems. The assumption is that plurality electoral systems distort the translation of votes into seats, discouraging and alienating small party supporters and other political minorities. In contrast, PR systems are believed to provide greater opportunities for representation which are assumed to instil greater efficacy and increase participation. We examine this theory linking institutions to electoral participation across a diverse set of countries using data from the Comparative Study of Electoral Systems. Using a multi-level approach we find evidence consistent with the expectations about the negative influence of disproportional systems on political minorities. Voters are also likely to have stronger partisan preferences in PR systems, which enhances political efficacy and increases voter participation. The effects of PR, however, are not all positive; broad coalitions, which are likely to be a feature of these systems, reduce political efficacy.
\end{abstract}

While the size of the advantage tends to vary, most of the research on electoral systems and turnout agrees that proportional representation (PR) systems have a turnout advantage. Although any one vote is unlikely to be decisive in an election, electoral systems can alter the degree to which votes can matter. Votes for minor parties in PR systems are likely to matter more in determining the overall partisan distribution of seats in a legislature than in plurality systems where minor parties often find it difficult to translate their votes into seats. Past research on electoral systems and turnout has assumed that the disproportionality between seats and votes in plurality systems instils in voters the feeling that their vote does not matter, and, as a result, they are less likely to vote. As such, attitudes towards the likely impact of one's vote are assumed to act as an intervening variable between electoral rules and electoral participation. The extant comparative literature, however, has relied almost entirely on aggregate data to examine the influence of electoral systems on voter turnout and, therefore, has never explicitly measured efficacy, the feeling that one's vote is potentially decisive. With the collection of cross-national election studies under the Comparative Study of Electoral Systems (CSES), it is now possible to examine how attitudes are shaped by electoral rules and how these attitudes influence turnout. We first review the evidence regarding the relationship between electoral systems, political efficacy, strength of partisan attachments and turnout. Based on this past research, we test a model of efficacy and electoral participation that combines electoral system and individual level effects.

\section{ELECTORAL SYSTEMS AND TURNOUT}

Most empirical studies that attempt to measure the impact of institutional arrangements on turnout do so by employing aggregate data across a number of countries with different

* Department of Politics, University of Exeter. The authors would like to thank Sarah Birch and the Journal's anonymous reviewers for their constructive comments. 
electoral systems. ${ }^{1}$ Although both the model specification and the selection of cases varies significantly from one study to another, most find that higher turnout is associated with countries that have proportional representation. ${ }^{2}$ These studies, however, are not conclusive when it comes to explaining how factors associated with PR facilitate higher turnout. For example, in an analysis of turnout in nineteen democracies over two decades, Jackman finds that proportional systems have a turnout advantage of about 9 percentage points over the most disproportional systems. ${ }^{3}$ However, the advantage is offset by the effects of multipartism, a characteristic of PR systems, which reduces turnout by as much as 12 percentage points.

In another study, Blais and Carty compare turnout in twenty parliamentary democracies with varying electoral systems from 1919 to 1985 and find turnout is about 7 per cent higher in PR systems than in plurality systems. ${ }^{4}$ However, they are unable to explain the reason for the difference as none of their measures through which PR is assumed to affect turnout (disproportionality, number of parties and competitiveness) are significant. A more recent study by Blais and Dobrzynska supports Jackman's initial conclusions; both proportionality and competitiveness foster higher turnout but the number of parties decreases turnout. They conclude that PR has both positive and negative effects on turnout and the overall impact is positive with PR countries having 3 per cent higher turnout. ${ }^{5}$

Because these studies are largely based on aggregate data, questions remain about whose electoral participation is most likely to be affected by electoral arrangements. Without individual-level data it is difficult to assess the importance of such individual characteristics as party preference and political efficacy and how these factors are related to the electoral system. In the following section we address four issues in the extant literature: (1) the influence of disproportionality, (2) the influence of multipartism, (3) the role of partisan attachments, and (4) the impact of the electoral system on political minorities.

\section{EFFECTS OF THE ELECTORAL SYSTEM}

The literature on electoral systems and turnout has proposed several paths linking efficacy and turnout to the electoral system. First, electoral systems have an influence on disproportionality of outcomes which can affect efficacy and turnout. Systems that distort the translation of votes into seats may alienate and discourage small or 'minor' party

${ }^{1}$ G. Bingham Powell Jr, 'American Voter Turnout in Comparative Perspective', American Political Science Review, 80 (1986), 17-43; André Blais and Agnieszka Dobrzynska, 'Turnout in Electoral Democracies', European Journal of Political Research, 33 (1998), 239-61. One notable exception is Cees van der Eijk and Mark Franklin, who examine the relative importance of institutional and individual level factors on electoral participation in elections to the European Parliament. These elections, however, by the authors' accounts are 'second order' elections that are widely perceived as unimportant and consequently 'fail to function as proper elections' (Cees van der Eijk and Mark Franklin, eds, Choosing Europe? The European Electorate and National Politics in the Face of Union (Ann Arbor: University of Michigan Press, 1996)).

2 Arend Lijphart, Patterns of Democracy: Government Forms and Performance in Thirty-Six Countries (New Haven, Conn.: Yale University Press, 1999), pp. 284-6.

${ }^{3}$ Robert Jackman, 'Political Institutions and Voter Turnout in Industrial Democracies', American Political Science Review, 81 (1987), 405-23

4 André Blais and R. K. Carty, 'Does Proportional Representation Foster Voter Turnout', European Journal of Political Research, 18 (1990), 167-81.

5 Blais and Dobrzynska, 'Turnout in Electoral Democracies', p. 251. 
supporters who are not fairly represented. ${ }^{6}$ A loss in political efficacy is likely to result in lower levels of political participation. ${ }^{7}$ Most of the cross-national studies on turnout show that disproportionality reduces turnout and this finding is consistent with the assumption that an unequal translation of votes into seats diminishes some people's sense of political efficacy leading them to abstain. ${ }^{8}$ Yet we do not know from these studies whether and to what extent political efficacy varies across electoral systems. Aside from efficacy, disproportionality may also influence turnout by shaping the strategies of parties and their candidates. Parties may campaign more actively when their chances of gaining representation improve. ${ }^{9}$

Secondly, electoral systems influence the number of political parties and multipartism can affect efficacy and turnout. Multipartism has been found to have both a negative and positive effect on turnout. ${ }^{10}$ Jackman infers that in multiparty systems where coalition governments are the norm, citizens are discouraged from voting when the formation of government is decided by political elites rather than by election outcomes. ${ }^{11}$ Therefore, as the number of parties and the likelihood of coalition governments increases, efficacy and the probability of voting will decline. However, election returns from Swiss communes, where majority and PR electoral systems are used, suggest that part of the boost in turnout gained in PR systems is from the increased number of parties. ${ }^{12}$ Such a finding is consistent with the expectation that parties increase turnout by mobilizing voters, strengthening partisan attachments and offering greater choice. These differing effects of multipartism indicate that a persuasive case can be made for either positive or negative effects. On the one hand, multipartism should promote efficacy and stimulate turnout by offering voters more choice. But, on the other hand, voters may also feel less efficacious when coalitions are the norm and governments are determined by party elites.

Thirdly, multipartism can also positively influence turnout by affecting strength of partisan attachments. Multi-party systems are more likely to occur under PR rules and in these systems there is a greater likelihood that parties will strive to distinguish themselves ideologically. ${ }^{13}$ If parties fail to offer a clear choice to voters, as they are hypothesized to

\footnotetext{
${ }^{6}$ Shaun Bowler, David Lanoue and Paul Savoie, 'Electoral Systems, Party Competition, and Strength of Partisan Attachment: Evidence from Three Countries', Journal of Politics, 56 (1994), 991-1007; Shaun Bowler and David Lanoue, 'Strategic and Protest Voting for Third Parties: The Case of the Canadian NDP', Western Political Quarterly, 45 (1992), 485-99.

${ }^{7}$ Gabriel Almond and Sidney Verba, The Civic Culture: Political Attitudes and Democracy (Princeton, N.J.: Princeton University Press, 1963); Pippa Norris, Electoral Engineering: Voting Rules and Political Behavior (New York: Cambridge University Press, 2004).

${ }^{8}$ Blais and Dobrzynska, 'Turnout in Electoral Democracies'; van der Eijk and Franklin, Choosing Europe?; Mark N. Franklin, 'Electoral Participation' in Laurence LeDuc, Richard G. Niemi and Pippa Norris, eds, Comparing Democracies: Elections and Voting in Global Perspective (Thousand Oaks, Calif.: Sage, 1996).

9 Jeffrey A. Karp, Susan A. Banducci and Shaun Bowler, 'Getting Out the Vote: Party Mobilization in a Comparative Perspective', British Journal of Political Science, 38 (2008), 91-112.

10 Jackman, 'Political Institutions and Voter Turnout in Industrial Democracies'; Mark Gray and Miki Caul, 'Declining Voter Turnout in Advanced Industrial Democracies, 1950-1997: The Effects of Declining Group Mobilization', Comparative Political Studies, 33 (2000), 1091-122; Andrea Ladner and Henry Milner, 'Do Voters Turn Out More under Proportional then Majoritarian Systems? The Evidence from Swiss Communal Elections', Electoral Studies, 18 (1999), 235-50.

11 Jackman, 'Political Institutions and Voter Turnout in Industrial Democracies'.

12 Ladner and Miller, 'Do Voters Turn Out More under Proportional then Majoritarian Systems?'.

13 Richard S. Katz, A Theory of Parties and Electoral Systems (Baltimore, Md.: Johns Hopkins University Press, 1980).
} 
do in two-party systems, voters are more likely to abstain. ${ }^{14}$ The larger number of parties and a tendency not to converge to the ideological centre in PR systems should increase the options from which voters can choose and result in fewer abstentions. Moreover, voters are more likely to have strong attachments to parties that cater more specifically to their needs, as opposed to catch-all parties that appeal to the median voter. Strength of partisan attachments has been found to be related to the electoral system. In systems that foster extreme parties, voters develop stronger attachments. ${ }^{15}$ Past research has also shown that voters with strong party attachments are more likely to be interested in politics, have higher levels of efficacy and are more likely to vote. ${ }^{16}$

Finally, there is little discussion of which voters will be advantaged or disadvantaged by the electoral arrangements; there may be a differential impact both in terms of efficacy and participation. For example, large-party supporters under plurality rules are not hypothesized to be discouraged from voting by the electoral system. However, it is difficult to distinguish between large-party and small-party supporters in the absence of individual data. Anderson and Guillory suggest that status as a political minority is an important variable when examining the influence of political institutions and satisfaction with democracy. ${ }^{17}$ Those supporting parties that were not in government were more likely to be satisfied with democracy in consensual systems that aim to restrain majority rule by requiring or encouraging the sharing of power between the majority and the minority. ${ }^{18}$ In contrast, in majoritarian systems, where power is concentrated in the hands of the majority, persons who recall voting for the losing party were more dissatisfied. The implementation of PR in New Zealand after a history of plurality elections also provides evidence that those supporting small parties were more likely to increase in efficacy and participation after the transition to a proportional system. ${ }^{19}$

\section{DIRECT AND INDIRECT EFFECTS ON VOTER PARTICIPATION}

Figure 1 illustrates the expected relationships between electoral systems, efficacy and turnout that we can draw from the discussion above. The figure illustrates that a number of factors associated with the electoral system directly affect participation and indirectly affect participation through efficacy. The direct and indirect effects of disproportionality are central to the model. We expect that disproportionality reduces both efficacy and turnout and conditions the relationship between minor-party preferences and efficacy. When institutional rules make it more difficult for small parties to gain representation, we

14 Anthony Downs, An Economic Theory of Democracy (New York: Harper and Row, 1957).

15 Bowler, Lanoue and Savoie, 'Electoral Systems, Party Competition, and Strength of Partisan Attachment'.

16 Angus Campbell, Phillip E. Converse, Warren E. Miller and Donald E. Stokes, The American Voter (New York: Wiley \& Sons, 1960); Sidney Verba, Norman H. Nie and Jae-On Kim, Participation and Political Equality: A Seven-Nation Comparison (Cambridge: Cambridge University Press, 1978).

17 Christopher J. Anderson and Christine A. Guillory, 'Political Institutions and Satisfaction with Democracy: A Cross-National Analysis of Consensus and Majoritarian Systems', American Political Science Review, 91 (1997), 66-81.

18 Arend Lijphart. Democracies (New Haven, Conn.: Yale University Press, 1984).

19 Susan A. Banducci, Todd Donovan and Jeffrey A. Karp, 'Proportional Representation and Attitudes about Politics: Evidence from New Zealand', Electoral Studies, 18 (1999), 533-55; Jack Vowles, Peter Aimer, Susan Banducci and Jeffrey Karp, eds, Voter's Victory? New Zealand's First Election Under Proportional Representation (Auckland: Auckland University Press, 1998); Jeffrey A. Karp and Susan A. Banducci, 'The Impact of Proportional Representation on Turnout: Evidence from New Zealand', Australian Journal of Political Science, 34 (1999), 363-77. 

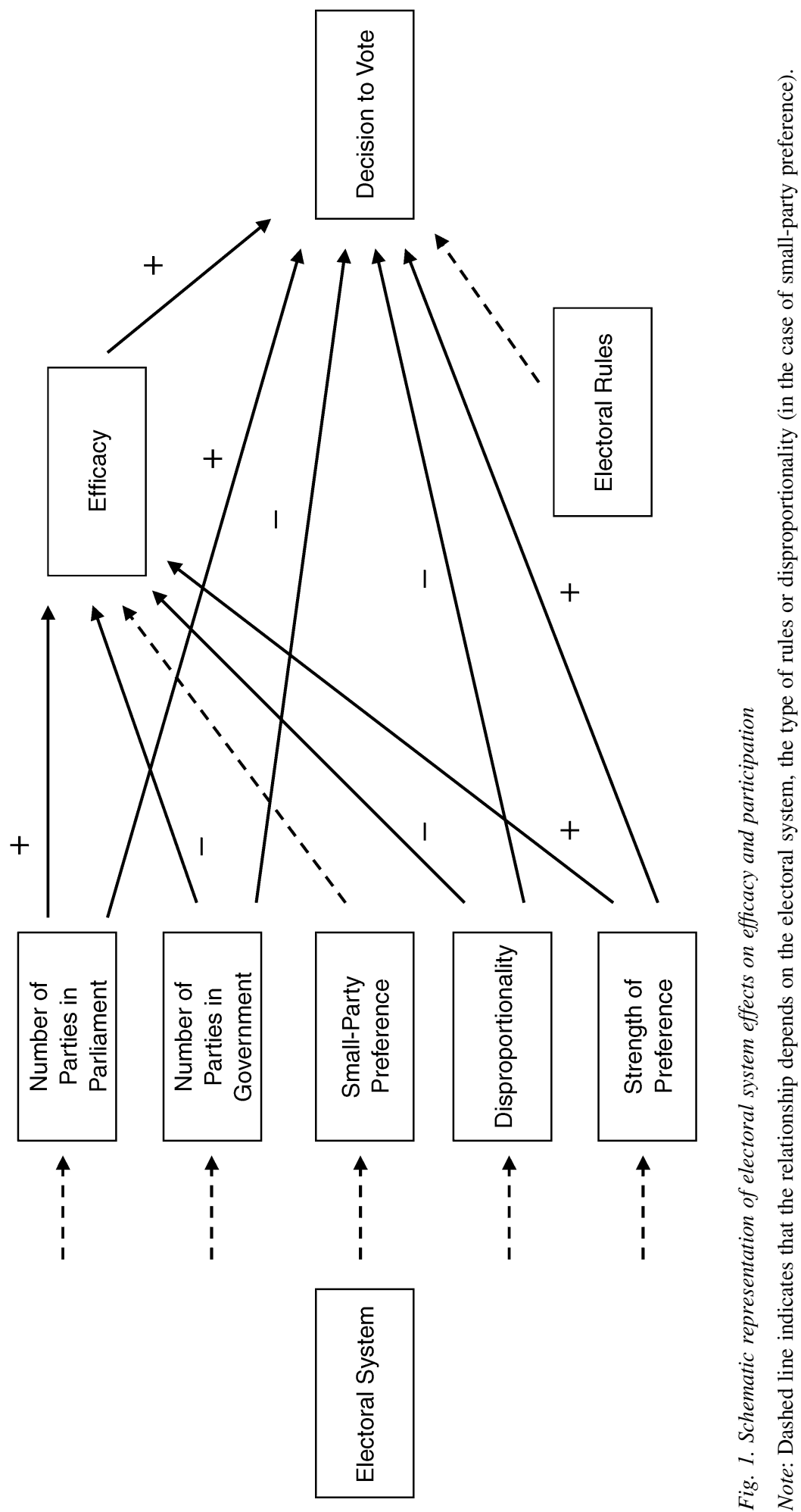
should expect those who prefer small parties to be more dissatisfied with the political system, have lower levels of efficacy, and, consequently, to be less likely to vote. Therefore, the effects of small-party preference on efficacy depend on the level of disproportionality.

To reconcile the contradictory expectations about the effects of multipartism on turnout, we distinguish between the number of parties holding executive power in a coalition government and the number of parties gaining representation in parliament. On the one hand, a citizen's feeling of efficacy, that her vote is important in determining a government and policy, may vary by the actual number of parties in government rather than the effective number of parties. After all, the number of coalition partners is arguably a more familiar feature of the party system than the number of effective parties to voters, commonly used in past research. Additionally, the potential for policy change, which would highlight the effect of voting on policy, has been shown to decrease as the number of parties in coalition government increases. ${ }^{20}$ Therefore we hypothesize that the number of parties in government will have a negative effect on efficacy. On the other hand, increased numbers of parties represented in parliament is expected to enhance efficacy and perhaps directly promote voter participation by mobilizing a wider diversity of interests.

Electoral systems are also expected to influence strength of partisan preference. In PR systems, citizens are more likely to develop stronger party attachments because they are more likely to adopt clear and consistent positions than in plurality and majoritarian systems where parties must widen their appeal to the broadest possible audience. Those with strong party preferences are more likely to feel efficacious and more likely to vote.

The model in Figure 1 also takes into account the effect of electoral rules that facilitate voting but are not likely to influence efficacy or other factors antecedent to efficacy in the model. Among the most effective rules for stimulating voting is compulsory voting, which regardless of the sanction for non-compliance can impose a small inducement that is enough to neutralize the cost of voting. ${ }^{21}$ While such a rule may enhance participation, it is not expected to enhance political efficacy.

\section{DATA}

Part of the difficulty in determining the relationship between electoral systems and turnout is the reliance on proxy variables and aggregate turnout to draw inferences about the interactions between institutions and individual behaviour. While aggregate cross-national studies are useful, these hypotheses are best tested with individual-level data. But such an approach requires a sample large enough to include citizens living under different combinations of institutional arrangements. The data must also include relevant variables such as measures of party preference and political participation that are collected in a comparable fashion. Although there have been several large cross-national surveys, none have contained the appropriate measures to examine voter participation. ${ }^{22}$ The

${ }^{20}$ George Tsebelis, 'Decision-Making in Political Systems: Veto Players in Presidentialism, Parliamentarism, Multicameralism and Multipartism', British Journal of Political Science, 25 (1995), 289-325.

${ }^{21}$ Arend Lijphart, 'Unequal Participation: Democracy's Unresolved Dilemma. Presidential Address, American Political Science Association, 1996', American Political Science Review, 91 (1997), 1-14, at p. 9.

${ }^{22}$ The World Values Surveys (1981-84; 1990-93) include a wealth of data from forty-five countries measuring political attitudes and confidence in political institutions. The International Social Survey Program (ISSP) is another valuable source for cross-national data on political behaviour and attitudes. However, since neither of these studies is conducted to coincide with an election, there is no direct measure of whether or not a citizen cast a ballot. 
Comparative Study of Electoral Systems (CSES) overcomes these limitations by relying on indigenous teams of researchers to administer a common module of questions either before or directly after a national election. ${ }^{23}$ We rely on data primarily from Module 1 (1996-2001) and supplement available data from other countries participating only in Module 2 (2001-06) to maximize the total number of countries that could be included for analysis. ${ }^{24}$ Our sample of countries along with their electoral systems are listed in Appendix Table A1. These unique data allow one to examine how institutions constrain individual behaviour in ways not previously possible. The diverse sample of countries available in the CSES also offers an advantage over other studies that often rely on data from advanced industrial states. Not only is there greater variation in context but individual level factors such as socio-economic status will have a greater range of values. ${ }^{25}$

The sample of countries can be divided into three general types of electoral systems: proportional representation, plurality or majoritarian, and mixed systems that combine plurality with PR in one chamber. ${ }^{26}$ Eighteen of the twenty-seven countries in our sample use PR to determine the overall partisan composition of the lower house. Among these systems, the diversity in electoral arrangements results in substantial variation in the degree to which translation of votes into seats results in proportionality. Among the factors accounting for differences is district magnitude which can have a strong impact on proportionality, with larger districts being associated with greater proportionality. ${ }^{27}$ Two of the countries, the Netherlands and Israel, have a single national district electing 150 and 120 members, respectively. Germany, New Zealand and Mexico also have a mixed member proportional (MMP) system, where about half of the members in parliament are selected by closed party lists to correct partisan imbalances resulting from the election of electorate candidates by plurality rules. Japan, Hungary, Russia, South Korea and Ukraine have non-corrective mixed systems, where some candidates are elected in single-member districts by either majority (as in the case in Hungary) or plurality (as in the case of Japan)

${ }^{23}$ CSES Secretariat, 'The Comparative Study of Electoral Systems Final Report of the 1995-96 Planning Committee' (Center for Political Studies: Ann Arbor: University of Michigan, 1996), < http://www.umich.edu/ $\sim$ nes/cses/final_report.html $>$.

${ }^{24}$ The Comparative Study of Electoral Systems $<$ www.cses.org $>$. CSES Module 1 Full Release (dataset). (Ann Arbor: University of Michigan, Center for Political Studies, 2003). This analysis relies on the 4 August 2003 'full release' of Module 1 (1996-2001). To increase the number of countries, data from the 29 June 2005 version of Module 2 (2001-06) have also been added. These countries include Belgium, Finland and Ireland. Countries holding only presidential elections have been excluded. Other countries that were included in this release have been excluded because of missing values or incomplete information. For further information about the CSES see: $<$ http://www.umich.edu/ nes/cses/cses.htm $>$.

25 Neil Nevitte, André Blais, Elisabeth Gidengil and Richard Nadeau, 'Socio-economic Status and Non-Voting: A Cross National Comparative Analysis' (paper presented at the 18th World Congress of the International Political Science Association, Quebec, 2000).

${ }^{26}$ At first glance, the CSES may appear to under-represent the number of plurality countries. The sample includes Canada, the United Kingdom and the United States. There are, however, few other plurality countries with established national election studies that could have been included (i.e. India). Similarly, according to Farrell's classification there are only three countries (Australia, France and Mali) with a majoritarian system. See David M. Farrell, Electoral Systems: A Comparative Introduction (New York: Palgrave, 2001), at p. 8. Given the small sample, we consider plurality and majority systems together since these systems represent one form of democracy that produce essentially the same electoral trends while PR systems represent another. See Farrell, Electoral Systems, at p. 63; Lijphart, Patterns of Democracy and G. Bingham Powell Jr, Elections as Instruments of Democracy: Majoritarian and Proportional Visions (New Haven, Conn.: Yale University Press, 2000).

27 Richard S. Katz, Democracy and Elections (New York: Oxford University Press, 1997), p. 134. 
rules, while others in the same chamber are elected by PR. The difference is that the PR component is not used as a corrective. ${ }^{28}$

Some countries also employ thresholds; higher thresholds are designed to keep the smallest parties out of parliament and affect the proportionality of seats to votes. In some cases, the threshold varies depending on whether a single party is standing alone or together with other parties (as is the case in the Czech Republic and Poland). In other cases, the threshold is both local and national, as is the case in Germany and New Zealand, where parties can enter parliament by either winning a constituency seat or by winning more than 5 per cent of the party vote.

Among the PR systems, Poland, Slovenia, the Czech Republic and Spain produce the most disproportional outcomes. These countries have either higher thresholds or small district magnitudes. The small district magnitude in Spain has repeatedly allowed the winning party to get a majority of seats with a plurality of votes. ${ }^{29}$ Australia uses the alternative vote for the lower house to achieve a majority. Instead of casting a single vote for a candidate, voters rank their preferences. If no candidate receives a majority, the candidate who receives the smallest number of first preferences is eliminated and the second preferences are then transferred to the other candidates until one candidate receives a majority. In the 1996 election, the system produced more disproportional results than any of the countries in our sample with mixed or PR systems but was somewhat more proportional than Britain or Canada.

\section{METHODS AND MEASUREMENT}

Our schematic representation in Figure 1 hinges on the role of efficacy as an intervening variable between the electoral system and the decision to vote. Therefore, measuring whether or not voters feel their vote makes a difference is important to the overall model. Since the introduction in the cross-national work on political culture and participation, the measurement of political efficacy has been the subject of debate. ${ }^{30}$ Internal efficacy refers to an 'individual's self-perceptions that they are capable of understanding politics and competent enough to participate in a political act such as voting' $\cdot{ }^{31}$ In contrast, external efficacy refers to 'expressed beliefs about political institutions' and the belief that leaders and institutions are responsive to the participation of individuals. ${ }^{32}$ If we intend to assess the extent of the psychological effect or how features of the electoral system affect efficacy,

\footnotetext{
${ }^{28}$ Hungary also has a mixed system where 176 members are elected by majority in single-member districts and 152 members are elected by PR. An additional fifty-eight national seats are used to correct some of the distortions that remain (see André Blais and Louis Massicotte, 'Electoral Systems' in Laurence LeDuc, Richard G. Niemi and Pippa Norris, eds, Comparing Democracies \#2: New Challenges in the Study of Elections and Voting (Thousand Oaks, Calif.: Sage, 2002), pp. 40-69, at p. 55). Since it is not entirely corrective, we classify it as a mixed system.

${ }^{29}$ Blais and Massicote, 'Electoral Systems', p. 57; Richard Gunther, 'Electoral Laws, Party Systems, and Elites: The Case of Spain', American Political Science Review, 83 (1989), 835-59. Disproportionality in Spain can also be attributed to malapportionment (see Arend Lijphart, Electoral Systems and Party Systems: A Study of Twenty-Seven Democracies, 1945-1990 (Oxford: Oxford University Press, 1994), at pp. 126-8).

30 Almond and Verba, The Civic Culture.

31 Warren E. Miller, Arthur H. Miller and Edward J. Schneider, American National Election Studies Data Sourcebook, 1952-1978 (Cambridge, Mass.: Harvard University Press, 1980); Richard G. Niemi, Stephen C. Craig and Franco Mattei. 'Measuring Internal Political Efficacy in the 1988 National Election Study', American Political Science Review, 85 (1991), 1407-13; Stephen C. Craig, 'Political Efficacy and Trust: A Report on the NES Pilot Study Items', Political Behavior, 12 (1990), 289-314.

${ }^{32}$ Miller, Miller and Schneider, American National Election Studies Data Sourcebook, 1952-1978.
} 
we are then interested in how the translation of seats to votes and elections affect the aspects of efficacy that are related to parties and elections.

Of the CSES items, the question that measures this aspect of efficacy asks respondents to place themselves on the following scale: 'Some people say that no matter who people vote for, it won't make any difference to what happens. Others say that who people vote for can make a difference to what happens.' The variable ranges from 1 to 5 with positive values indicating higher levels of efficacy. ${ }^{33}$ This question is the most direct measure of evaluations of the efficacy of a vote available and, thus, how the electoral system translates votes into seats. In terms of face validity, this question asks respondents to evaluate the meaningfulness of voting, a component of elections as an accountability mechanism, and, therefore, should be the most direct measure of the feelings of efficacy that can be attributed to the act of voting. ${ }^{34}$

To measure party preference, we rely on a series of items that measure evaluations of up to six parties employing a ten-point scale ranging from 'Strongly like' to 'Strongly dislike'. Using this series of party evaluations, the preferred party can be identified as the party that is most positively evaluated by the respondent. The CSES also asks respondents whether they think of themselves as being close to any political party and if so to identify that party (additional parties are coded only if the respondent volunteers). This measure is analogous to the traditional party identification measure associated with the Michigan school of voting behaviour. ${ }^{35}$ The problem with this measure is that a majority of respondents in the sample claim not to be close to any party. ${ }^{36}$ In comparison, 74 per cent of the sample evaluate one party more highly than another. About 22 per cent of the sample evaluated more than one party equally, while just 4 per cent said that they were unaware or did not know about any of the parties. Therefore, we rely on the party preference measure for the analysis and report instances where the results would differ if the party closeness measure were used instead.

An indicator of how much someone favours a party can be obtained by taking the value given on the likes and dislikes scale that ranges from 0 to 10 . We refer to this as strength of party preference though it should be noted that this is not the same thing as the traditional party identification measure. High values indicate a strong preference for a party (or parties), while lower values indicate a weaker preference. Less than 1 per cent of the sample who evaluated at least one party failed to rank a single party above 0 . If the preference

33 About 3 per cent of the total cases are missing, of which less than half are coded as 'don't know'. These missing cases are not evenly distributed across countries. Some of these missing values correspond to missing values on other variables suggesting that the problem is not unique to this variable. Since we cannot be sure why these cases are missing, they have been dropped from the analysis.

${ }^{34}$ Empirical evidence also supports this view. We compared the CSES measure with other measures of efficacy available in four national election studies. The findings are consistent with Acock, Clarke and Stewart who find that a two-factor solution (internal and external dimensions) to the efficacy indicators fits across a number of countries. See Alan Acock, Harold D. Clarke and Marianne C. Stewart, 'A New Model for Old Measures: A Covariance Structure Analysis of Political Efficacy', Journal of Politics, 47 (1985), 1062-84. In all four election studies, the CSES item loaded most strongly with the other items measuring external efficacy. Therefore, there is clear evidence that the CSES item measures an aspect of external efficacy. These results can be obtained at $<$ http://www.jkarp.com/bjps/ $>$.

35 Samuel H. Barnes, M. Kent Jennings, Ronald Inglehart and Barbara Farah, 'Party Identification and Party Closeness in Comparative Perspective', Political Behavior, 10 (1988), 215-31.

${ }^{36}$ Specifically 43 per cent of the sample responded that they were close to a political party and 5 per cent refused to answer the question. Moreover, fewer people feel close to small parties. For example, in the United States, only ten respondents feel close to the Reform party while eighty-six respondents express a preference for that party over the Republican and Democratic parties. 
is for one of the two largest parties, the respondent is identified as having a preference for a large party. Generally, parties that receive at least 20 per cent of the vote are classified as large parties. For example, in Germany, the Christian Democratic Union (CDU) and the Social Democratic Party of Germany (SPD) are classified as large parties, receiving 41 and 28 per cent of the vote in 1998 respectively. In most countries, this classification scheme produces two large parties but in some countries, such as Canada, Norway and Ukraine, only one party received at least 20 per cent of the vote. All others are coded as small parties.

One of the frequently cited limitations with using survey data involves the validity of the responses, particularly with regard to political participation. It is not uncommon in election studies to find that the proportion of respondents who report voting is far greater than the aggregation of election returns. One of the theories commonly advanced to explain this discrepancy is that non-voters are motivated to give a socially desirable response. Voter validation studies in the United States have confirmed that a bias towards over-reporting exists where the overwhelming majority of error occurs among non-voters who claim to have voted, rather than vice versa. ${ }^{37}$ According to voter validation studies in the United States, about 15-30 per cent falsely claim to have voted compared to less than 5 per cent of voters who falsely deny having voted. ${ }^{38}$ Similar results have been found elsewhere. ${ }^{39}$ It has been assumed that the social desirability bias is a general human trait that affects everyone equally but recent research suggests that respondents are also likely to be influenced by the electoral context. ${ }^{40}$ Nevertheless, since mis-reporting occurs primarily among non-voters, the overall bias between reported and actual turnout in any given country will depend on the proportion of non-voters. The CSES advised collaborators to ask the question in a way that minimized over-reporting. ${ }^{41}$ For the purposes of our analysis, non-responses to this question were assumed to be non-voters. Unfortunately, it is not possible to estimate the degree of over-reporting in the CSES as only a handful of election studies are able to independently verify whether a respondent cast a ballot. Therefore, we have weighted the data by the actual turnout on the basis of the age-eligible population to correct for these differences, so that non-voters, who are under-represented in the surveys, are given more weight. We have also weighted the data to correct for unequal sample sizes across countries.

37 Brian D. Silver, Barbara A. Anderson and Paul R. Abramson, 'Who Overreports Voting?' American Political Science Review, 80 (1986), 613-24; Michael W. Traugott and John P Katosh, 'Response Validity in Surveys of Voting Behavior', Public Opinion Quarterly, 43 (1979), 359-77.

38 Aage R. Clausen, 'Response Validity: Vote Report', Public Opinion Quarterly, 32 (1968), 588-606; Traugott and Katosh, 'Response Validity in Surveys of Voting Behavior'; Silver, Anderson and Abramson, 'Who Overreports Voting?'

39 Kevin Swaddle and Anthony Heath. 'Official and Reported Turnout in the British General Election of 1987', British Journal of Political Science, 19 (1989), 537-70; Donald Granberg and Soren Holmberg, 'Self-Reported Turnout and Voter Validation', American Journal of Political Science, 35 (1991), 448-59; Karp and Banducci, 'The Impact of Proportional Representation on Turnout'.

40 André Blais, To Vote or Not to Vote: The Merits and Limits of Rational Choice Theory (Pittsburgh: University of Pittsburgh Press, 2000), p. 176; Henry E. Brady, Sydney Verba and Kay Lehman Schlozman, 'Beyond SES: A Resource Model of Political Participation', American Political Science Review, 89 (1995), 271-95, p. 292; Jeffrey A. Karp and David Brockington, 'Social Desirability and Response Validity: A Comparative Analysis of Over-reporting Voter Turnout in Five Countries' Journal of Politics, 67 (2005), 825-40.

${ }^{41}$ For example the British Election Study asked, 'Talking to people about the general election, we have found that a lot of people didn't manage to vote. How about you - did you manage to vote in the general election?' Similarly in Switzerland the question was asked, 'On average, about half of the electorate casts a ballot at federal elections. How about you? Did you cast a ballot at the federal elections on October 24?' 
PARTISAN DIFFERENCES IN EFFICACY AND TURNOUT BY ELECTORAL SYSTEM

Figure 1 shows that the electoral system should influence both efficacy and the nature of partisan preferences, so we first examine these differences across the three types of electoral systems in Table 1. Not surprisingly, in plurality and majoritarian systems more people prefer large parties than in PR or mixed systems. About a third of the electorate expresses a preference for small parties in PR compared to about a fifth in plurality or majoritarian systems. Excluding Canada, just 12 per cent express a preference for small parties in the remaining plurality systems and Australia. Mixed systems have the highest proportion without a single preference suggesting that these systems might encourage multiple party attachments. These systems also have the highest proportion who do not express a preference for any of the parties. As is evident from Table 1, citizens in PR systems have the strongest preferences (top two categories on like-dislike scale), while those in plurality systems have the weakest. Specifically, about 30 per cent strongly preferred a party in plurality systems compared to 39 per cent in PR systems. ${ }^{42}$ Together these findings are consistent with expectations that PR systems increase the options for which voters can choose, which helps to foster stronger attachments to political parties.

Table 2 reports the influence of party preference on efficacy and turnout by electoral system. Despite the cultural differences between PR countries, they have far higher levels of efficacy than those found in plurality systems. Canada has the lowest levels of efficacy of any country in the sample, with just 14 per cent placing themselves in the top category of efficacy. Moreover the differences in efficacy between those who prefer large and small parties are substantial in plurality systems and negligible in the mixed systems. Those who prefer large parties in PR systems are also more likely than those preferring small parties to feel efficacious though the difference is not as great. A closer examination of these differences within plurality and majority countries (not reported in the table) indicates that the difference is largest in the United States and smallest in Canada. Nevertheless, those

TABLE $1 \quad$ Distribution of Party Preferences by Electoral System

\begin{tabular}{lcccccr}
\hline \hline & \multicolumn{6}{c}{ Most preferred party } \\
\cline { 2 - 5 } & $\begin{array}{c}\text { Large } \\
\text { party }\end{array}$ & $\begin{array}{c}\text { Small } \\
\text { party }\end{array}$ & $\begin{array}{c}\text { No single } \\
\text { preference }\end{array}$ & $\begin{array}{c}\text { Strongly } \\
\text { like }\end{array}$ & $\begin{array}{c}\text { Don't } \\
\text { know }\end{array}$ & $n$ \\
\hline PR & 40.2 & 29.8 & 26.0 & 38.5 & 4.0 & 22,575 \\
Mixed (non-corrective) & 38.8 & 21.9 & 34.1 & 37.8 & 5.2 & 6,215 \\
Plurality/Majority & 54.9 & 21.0 & 21.9 & 29.9 & 2.2 & 5,009 \\
Total & 42.1 & 27.0 & 26.9 & 37.1 & 3.9 & 33,799 \\
\hline \hline
\end{tabular}

Note: Data are weighted to adjust for unequal sample size and over-reported vote. Each country's sample is approximately 1,250. 'No single preference' indicates those who gave the same score for two or more parties. 'Don't know' indicates those who responded 'Don't know' on all party rankings.

\footnotetext{
42 The proportion claiming to be close to a party is slightly higher in plurality systems than in PR systems. However, the proportion who are very close to a party is the same across systems (see < http://www.jkarp.com/ bjps/ $>$ ). Given the strong theoretical expectations that attachments to parties varies across electoral systems and the lack of variance in party proximity measures suggests that our alternative measure (which does vary across systems) is more appropriate.
} 
TABLE 2 Political Efficacy and Participation by Electoral System and Party Preference

\begin{tabular}{|c|c|c|c|c|c|c|}
\hline & \multicolumn{5}{|c|}{ Most preferred party } & \multirow[b]{2}{*}{ Total } \\
\hline & $\begin{array}{l}\text { Large } \\
\text { party }\end{array}$ & $\begin{array}{l}\text { Small } \\
\text { party }\end{array}$ & $\begin{array}{l}\text { No single } \\
\text { preference }\end{array}$ & $\begin{array}{l}\text { Strongly } \\
\text { like }\end{array}$ & $\begin{array}{c}\text { Difference } \\
\text { (Large - } \\
\text { Small) }\end{array}$ & \\
\hline \multicolumn{7}{|l|}{ Efficacy* } \\
\hline PR & 48.3 & 40.0 & 38.4 & 55.3 & 8.4 & 42.8 \\
\hline Mixed (non-corrective) & 39.3 & 38.8 & 34.9 & 49.7 & 0.5 & 36.8 \\
\hline Plurality/Majority & 35.8 & 20.8 & 27.6 & 47.1 & 15.0 & 30.7 \\
\hline Total & 46.8 & 25.5 & 24.4 & 53.3 & 21.4 & 39.9 \\
\hline \multicolumn{7}{|l|}{ Reported Turnout } \\
\hline PR & 77.7 & 76.5 & 67.2 & 82.1 & 1.2 & 72.9 \\
\hline Mixed (non-corrective) & 68.0 & 66.5 & 57.0 & 74.2 & 1.4 & 61.5 \\
\hline Plurality/Majority & 71.8 & 67.7 & 62.0 & 83.0 & 4.2 & 68.1 \\
\hline Total & 74.9 & 74.0 & 64.2 & 80.7 & 0.9 & 70.1 \\
\hline
\end{tabular}

*Figures indicate percentage who are in the highest category of efficacy. Data are weighted (as above).

who prefer small parties in each of the plurality and majority countries feel less efficacious than those who prefer large parties, which provides support for our initial hypothesis that these types of systems discourage those who prefer small parties. Similar results are found when using the party closeness measure. ${ }^{43}$ The gap between large-party and small-party identifiers is twice as great in plurality systems when compared to PR systems.

Lower levels of efficacy are also evident among those not having a single party preference. Those who neither strongly like nor strongly dislike parties are less efficacious than those who strongly like parties. Similarly those who do not consider themselves to be close to a party are less likely to be efficacious than those who consider themselves to be very close. Of course it is possible that the causal arrow may be reversed and that the differences observed here simply indicate that the least efficacious citizens are likely to care less about parties than the most efficacious. If this were true one should expect those with low levels of efficacy to dislike all parties. But this is not the case. The average ranking of parties is only weakly correlated with efficacy $(r=0.09)$ while the single highest ranking is strongly correlated with efficacy $(r=0.47)$. This indicates that citizens who strongly like a particular party are likely to have higher levels of efficacy and they are also likely to hold quite different views about other parties. In short, positive evaluations of parties in general are not related to efficacy but evaluations of specific parties are. This relationship suggests that it is much more likely that strong attachments make voters feel more efficacious rather than efficacy making voters more positive about parties in general.

The bottom section of Table 2 reports voter participation by electoral system and party preference. The differences in participation between plurality and PR systems match those

${ }^{43}$ These results can be obtained at $<$ http://www.jkarp.com/bjps/ $>$. 
found by others. In our sample, the PR systems on average have about 5 per cent higher turnout than in the plurality and majoritarian systems. The difference increases when Australia, which has compulsory voting, is excluded. These findings approximate those of Blais and Carty who found a 7 per cent difference comparing twenty parliamentary democracies over a sixty-year period. ${ }^{44}$ The results show that those who prefer small parties in all systems are, on average, less likely to participate than large-party supporters. Those with no single preference are also less likely to participate than those with large-party preference. Larger differences are evident among those who did express a preference for any party, suggesting that lacking a party preference has a large influence on turnout.

INDIVIDUAL AND SYSTEMIC DETERMINANTS OF EFFICACY AND TURNOUT

Our initial examination of the data suggests some support for our hypotheses. In particular, the findings demonstrate that electoral systems can influence party preferences and shape attitudes about efficacy. We now turn to a multivariate analysis to investigate this issue further. To estimate the psychological effect, a measure of the disproportionality of the system is included in the model. ${ }^{45}$ Since disproportionality is likely to disadvantage small parties, we include an interaction term between small-party preference and disproportionality. Other dummy variables are used to identify the nature of party preferences leaving those who prefer large parties in the referent category. We also include strength of party preference (as discussed above), which should be positively associated with both efficacy and turnout. Those who do not express a party preference are coded 0 on this scale while those with the strongest preferences are coded $10 .{ }^{46}$ We expect those who are older as well as those with higher levels of education to feel more efficacious and be more likely to vote. To ease the interpretation of the coefficient, education, which has eight categories, has been standardized to range from low education (0) to high education (1). Age and gender are also used in the model as controls.

Along with disproportionality, several other contextual variables are included to test hypotheses discussed earlier. The number of parties gaining over 2 per cent of the seats in parliament is used to measure diversity in the representation of parties. To measure the effects of coalition government, we use the number of parties represented in government prior to the election. ${ }^{47}$ Although increased representation of parties in parliament may lead to broader coalition governments, the two measures are not highly correlated $(r=0.35)$. There is also a reason to believe that where the outcome is expected to be close citizens may feel more efficacious and be more likely to participate. ${ }^{48}$ To take this into account, we control for the closeness of the election by including a measure of the difference

44 Blais and Carty, 'Does Proportional Representation Foster Voter Turnout.'

45 The measure is derived from Gallagher's least squares index and is based on the election when the survey was conducted. See Michael Gallagher. 'Proportionality, Disproportionality and Electoral Systems', Electoral Studies, 10 (1991), 33-51.

46 The models were estimated with and without 'No preference' (which account for less than 5 per cent of the sample) to determine whether this influenced the effects for strength of preference. The effects remained the same.

47 Franklin uses the size of the largest party to measure the decisiveness of elections. While this measure may be correlated with the size of a government coalition it is not necessarily the same. See Mark N. Franklin, Voter Turnout and the Dynamics of Electoral Competition in Established Democracies Since 1945 (New York: Cambridge University Press, 2004).

${ }^{48}$ Franklin, Voter Turnout and the Dynamics of Electoral Competition in Established Democracies Since 1945. 
between the two top vote winners at the national level. ${ }^{49}$ Because the sample includes countries in various stages of democratic development, a dummy variable is used to identify the eight new democracies in the sample (see Appendix Table A1 for coding). Australia, Belgium, Mexico and one canton in Switzerland have compulsory voting, though these countries differ in how the law is enforced. Since this is one electoral rule that is intended to increase the likelihood of voting, but is not designed to influence efficacy, we include a dummy variable in the turnout model as a control.

Our method of estimating the effects of institutional and individual level factors on efficacy and participation must take into account two features of the data. First, the variables in which we are interested are measured at two different levels - the individual level (unweighted $n=45,268)$ and the country level $(n=27)$. In our model, we also suggest that there is cross-level interaction between small-party preference (an attribute measured at the individual level) and disproportionality (an attribute measured at the country level). Secondly, and not unrelated to the first, the CSES dataset is comprised by pooling cross-sectional election studies from individual countries. Therefore, respondents are sampled from different clusters (countries). If individuals living within each country share common characteristics on unmeasured variables, as they are likely to do, the assumption that the error variance will be independent across countries is violated. Because the data are multi-level and sampled from within units, most conventional methods of estimation will underestimate standard errors, particularly at the second or macro level, leading to a higher probability of rejection of a null hypothesis. Therefore, we rely on estimation techniques that are specific to modelling multilevel data structures. ${ }^{50}$ In our analysis, this estimation method does not significantly affect coefficients but it does estimate more consistent standard errors, particularly at the macro-level, when some of the assumptions about variance are violated. ${ }^{51}$

\section{RESULTS}

All models reported were estimated using MLwiN (version 2.02). The results of the model predicting the highest level of vote efficacy are reported in Table $3 .{ }^{52}$ To facilitate the interpretation of the logit coefficients we also report the unlogged coefficient which represents how much the odds of having the highest level of efficacy are increased by a one-unit change in the independent variable. In response to the hypotheses set out earlier, there are three important points that should be noted. First, citizens who prefer small parties are less likely to feel efficacious than citizens who prefer large parties. The negative interaction term between small-party preference and disproportionality indicates that these effects increase as the system becomes more disproportional.

${ }^{49}$ It was not possible to apply the measure below the national level in all districted systems because of missing data in a number of countries.

50 Marco R. Steenbergen and Bradford Jones, 'Modeling Multilevel Data Structures', American Journal of Political Science, 46 (2002), 218-37; Stephen W. Raudenbush and Anthony S. Bryk, Hierarchical Linear Models: Applications and Data Analysis Methods (Thousand Oaks, Calif.: Sage, 2002).

51 Estimations based on treating the data as structured by a single level of measurement and adjusting for standard errors for clustering at the country level are available from the authors. When comparing estimates from traditional logit models to multilevel logit models, the largest differences occur in the estimation of standard errors for factors measured at the country level.

${ }^{52}$ We report the results of a binary logit model predicting only the highest level of efficacy. In other analyses (available from the authors), we estimated an ordered logit model. The results are essentially the same although the coefficients are obviously altered. 
TABLE 3 Multi-level Model of Efficacy: Logit Estimates

\begin{tabular}{lccc}
\hline \hline & Coef. & $\begin{array}{c}\text { Robust } \\
\text { s.e. }\end{array}$ & $\begin{array}{c}\text { Odds } \\
\text { ratio } \dagger\end{array}$ \\
\hline Level 1 Variables & & & \\
Small party preferred & $-0.11^{*}$ & $(0.05)$ & 0.90 \\
No single party & $-0.08^{* *}$ & $(0.04)$ & 0.93 \\
Strength of preference & $0.15^{* *}$ & $(0.02)$ & 1.17 \\
Age (in 10s) & $0.07^{* *}$ & $(0.01)$ & 1.07 \\
Education & $0.21^{* *}$ & $(0.09)$ & 1.23 \\
Female & 0.01 & $(0.02)$ & 1.01 \\
& & & \\
Level 2 Variables & & & \\
Parties in parliament & -0.04 & $(0.06)$ & 0.96 \\
Parties in government & $-0.40^{* *}$ & $(0.14)$ & 0.67 \\
New democracies & 0.01 & $(0.21)$ & 1.01 \\
Disproportionality & $-0.08^{* *}$ & $(0.03)$ & 0.93 \\
Competitiveness & 0.02 & $(0.02)$ & 1.02 \\
Cross-level Interaction & & & \\
Disproportionality $\times$ small party preferred & $-0.02^{* *}$ & $(0.01)$ & 0.98 \\
Constant & -0.46 & $(0.55)$ & \\
Random Effects Level 2 & & & \\
Intercept & & & \\
Strength of Preference & $0.70^{* *}$ & $(0.23)$ & \\
Total Variance (individual level variables only) & $0.003^{* *}$ & $(0.00)$ & 1.00 \\
Total Variance (full model) & 0.61 & & \\
Chi-square fixed effects & 315.49 & $(14 \mathrm{df})$ & \\
Chi-square random effects & 10.86 & $(2 \mathrm{df})$ & \\
Number of level one units & 33,595 & & \\
Number of level two units & 27 & & \\
\hline \hline
\end{tabular}

$* * p<0.01 ; * p<0.05$

$\dagger$ Odds ratio is the unlogged coefficient which represents the odds that a citizen increases to the highest level of efficacy given a one unit change in the independent variable.

Secondly, strength of party preference has the strongest impact of any of the variables in the model. Moving from the weakest party preference to the strongest increases the odds of having the highest level of efficacy by over four times. ${ }^{53}$ These effects are consistently strong in every country when the models are estimated separately and the effect varies significantly within countries. We have taken this into account by allowing for random effects of strength of party preference at the country level.

Thirdly, the number of parties represented in government has a negative impact on efficacy. This finding is consistent with the expectation that voters will feel they have less influence when there are broad coalitions. This result provides the most direct evidence that voters are sensitive to the decisiveness of elections and helps to explain why broad

53 The odds ratio for a ten unit change in strength of party preference is 4.48 . 
coalitions may depress voter turnout. While broad based coalitions depress efficacy, the number of parties in parliament appears to have no effect at all. ${ }^{54}$ Other factors strongly influencing efficacy are age and the level of formal education. Numerous studies have demonstrated that the well educated are likely to have a strong sense of political efficacy. ${ }^{55}$ Age is also known to influence efficacy though some studies have failed to find a significant relationship. ${ }^{56}$

We now turn to an examination of the relationship between efficacy and voter participation. ${ }^{57}$ Because efficacy is assumed to be a link between the electoral system and voter participation, one of our main interests is how contextual factors moderate the relationship between efficacy and voter participation. Figure 2 is used to illustrate how the influence of efficacy on the probability of voting varies across the twenty-seven countries in our sample, and how these effects change with the addition of macro-level variables. The top of Figure 2 shows the effect of efficacy on voting in each of the twenty-seven countries in the sample. The dark line represents the population averaged slope while the lighter lines indicate the slope in each country. These probabilities are based on estimating an individual-level model only with random effects for the intercept and for efficacy. The variation in the intercept (along the $y$-axis) for each slope indicates significant variation across countries in the probability of voting and the differences in the slope indicate that the strength of the effect of efficacy varies across countries, though the effect is always positive. The bottom of Figure 2 shows the random effects of efficacy once the macro-level variables have been added to the model. The addition of the macro-level variable reduces the variation in the intercepts between the countries as well as reducing the variation in the slope of efficacy for the individual countries. The figures illustrate that, while efficacy has an impact on voting, contextual factors play a role in moderating these effects.

The coefficient estimates for the full model predicting the likelihood of voting are presented in Table 4. Strength of partisan preference also has a large influence on the probability of voting independent of efficacy; those with the strongest preference are eight times more likely to vote than those with no preference at all. ${ }^{58}$ These results provide a better understanding for how PR systems influence turnout; they do so in part by fostering stronger party preferences (see Table 1). Although not included in the reported analysis,

\footnotetext{
54 The number of parties in parliament and disproportionality are correlated $(-0.54)$. When disproportionality is not included in the model, the number of parties has a stronger influence. Several transformations of these variables were tested. All transformations performed equally, so we used the linear function.

55 Bernadette C. Hayes and Clive S. Bean, 'Political Efficacy: A Comparative Study of the United States, West Germany, Great Britain and Australia', European Journal of Political Research, 23 (1993), 261-80.

56 Almond and Verba, The Civic Culture; Cliff Zukin, Scott Keeter, Molly Andolina, Krista Jenkins and Michael X. Delli Carpini, A New Engagement? Political Participation, Civic Life, and the Changing American Citizen (Oxford: Oxford University Press, 2006), at pp. 118-19.

57 It is possible that the relationship between efficacy and participation is reciprocal. That is, once citizens have participated, their level of efficacy will increase. Unfortunately, our reliance on cross-sectional data makes it almost impossible to test this hypothesis. See Steven E. Finkel, 'Reciprocal Effects of Participation on Political Efficacy: A Panel Analysis', American Journal of Political Science, 29 (1985), 891-913, p. 894. Moreover, to our knowledge the efficacy measure used by the CSES does not appear to have been asked both before and after an election so it is not possible to test the hypothesis with other data. Nevertheless, we believe that it is reasonable to characterize the relationship as one where efficacy influences voter participation. In terms of face validity, the question about efficacy is asked in the present tense rather than in the past tense, which forces citizens to think in more general terms rather than in the context of the recent electoral outcome and their past participation.

${ }^{58}$ Similar to the efficacy model, the effect of strength of party preference varies significantly across countries. Therefore, like the efficacy model, we have allowed for random effects at the country level.
} 


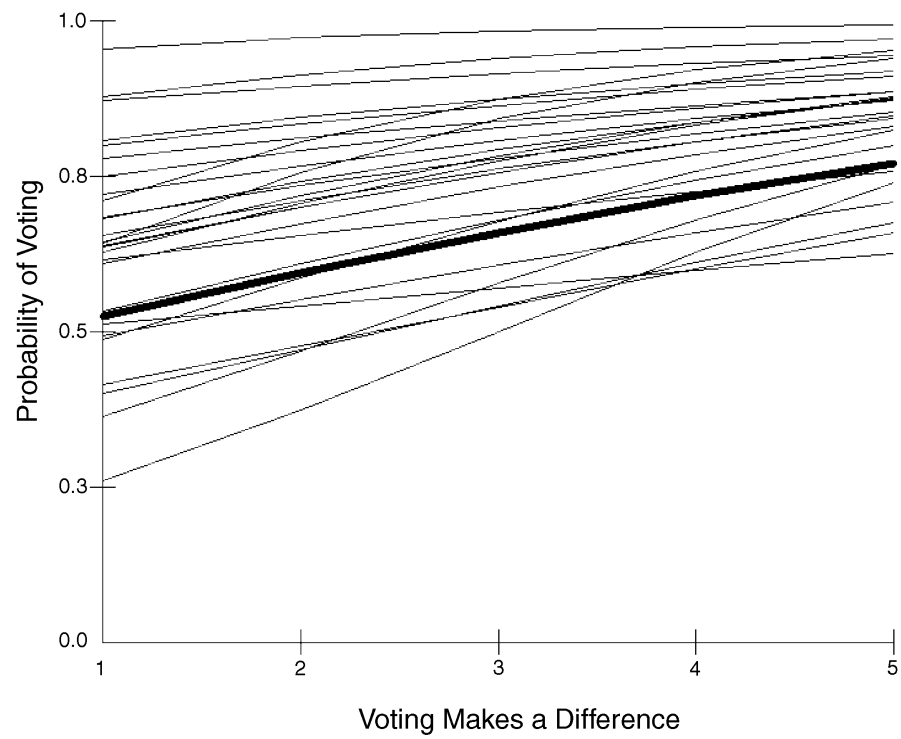

(a) Base model with random effects for intercept and efficacy

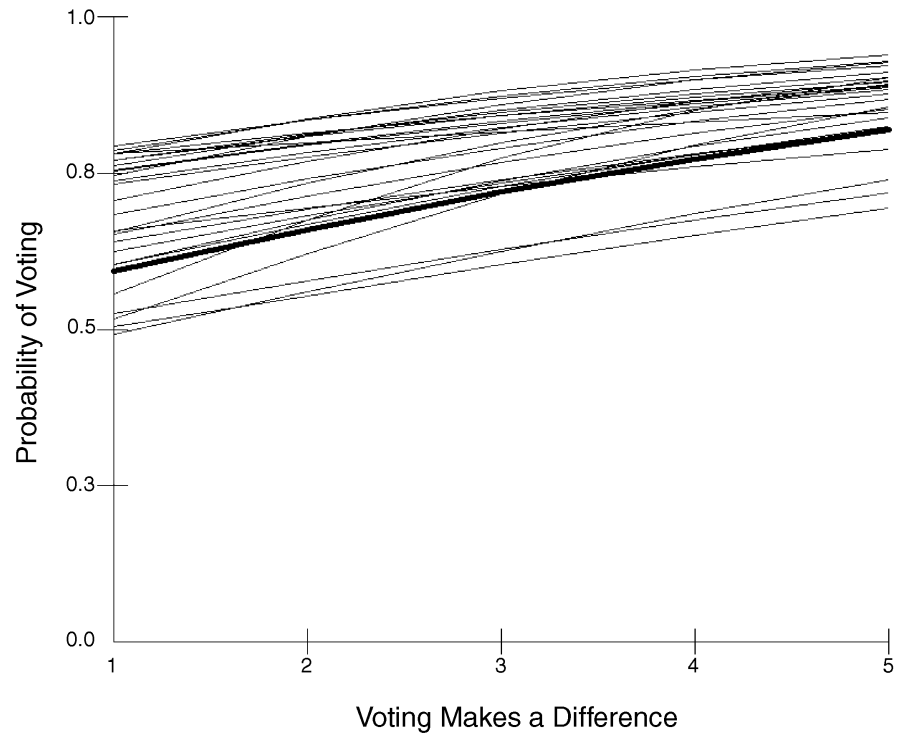

(b) Model with random effects controlling for macro level characteristics

Fig. 2. Effects of efficacy on the probability of voting

we also investigated whether citizens holding more negative opinions about parties were more or less motivated to participate in the political process. ${ }^{59}$ While PR systems tend to foster stronger positive evaluations of parties (see Table 1), they also appear to encourage stronger negative opinions as well. In PR systems, 56 per cent of respondents gave a party

59 In this case, we constructed a variable that measured the lowest party evaluation. If a person strongly disliked one party and strongly liked another, they would receive a high score on both preference measures. 
TABLE 4 Multi-level Model of Voter Participation: Logit Estimates

\begin{tabular}{lccc}
\hline \hline & Coef. & $\begin{array}{c}\text { Robust } \\
\text { s.e. }\end{array}$ & $\begin{array}{c}\text { Odds } \\
\text { ratio } \dagger\end{array}$ \\
\hline Level 1 Variables & & & \\
Small party preferred & -0.13 & $(0.07)$ & 0.88 \\
No single party & $-0.18^{* *}$ & $(0.06)$ & 0.84 \\
Strength of preference & $0.21^{* *}$ & $(0.02)$ & 1.23 \\
Age (in 10s) & $0.21^{* *}$ & $(0.01)$ & 1.23 \\
Education & $1.14 * *$ & $(0.18)$ & 3.13 \\
Female & -0.07 & $(0.04)$ & 0.93 \\
Efficacy & $0.21^{* *}$ & $(0.02)$ & 1.23 \\
& & & \\
Level 2 Variables & & & \\
Parties in parliament & 0.13 & $(0.08)$ & 1.14 \\
Parties in government & $-0.40^{* *}$ & $(0.14)$ & 0.67 \\
New democracies & $-0.92^{* *}$ & $(0.30)$ & 0.40 \\
Disproportionality & -0.02 & $(0.03)$ & 0.98 \\
Competitiveness & $0.05 * *$ & $(0.02)$ & 1.05 \\
Compulsory voting & $1.35 * *$ & $(0.39)$ & 3.86 \\
Constant & $1.93 * *$ & $(0.56)$ & \\
Random Effects & & & \\
Constant & & & \\
Efficacy & & & \\
Total Variance (individual level variables only) & $0.43 * *$ & $(0.08)$ & \\
Total Variance (full model) & 0.29 & & \\
Chi-square fixed effects & $768.94(15 \mathrm{df})$ & & \\
Chi-square random effects & $19.54(2 \mathrm{df})$ & & \\
Number of level one units & 33,361 & & \\
Number of level two units & 27 & & \\
\hline \hline
\end{tabular}

$* * p<0.01 ; * p<0.05 ;{ }^{\mathrm{a}} p<0.10$

$\dagger$ Odds ratio is the unlogged coefficient which represents the odds that a citizen votes given a one unit change in the independent variable.

a score of 0 or 1 on the ten-point scale. The results indicate that holding more negative opinions, while not as strong as the influence of positive evaluations, nevertheless increases the odds of voting. The effects of the individual-level control variables in the model are also largely consistent with expectations; both age and education serve to enhance voter participation.

As noted above, citizens are less likely to believe that their vote matters in systems that produce large coalitions. The size of the government coalition also has a direct and negative impact on voting even after controlling for efficacy. This indicates that coalition size reduces voter participation independent of political efficacy. We suspect that party mobilization is a factor, though we have no direct way of measuring it with these data. Another possible explanation is that Switzerland, a country with large coalitions and low turnout, may be driving the results. ${ }^{60}$ National competitiveness is positive and significant,

${ }^{60}$ When efficacy is omitted from the model and Switzerland is included as a dummy variable, coalition size is no longer significant. Franklin argues that it is not the size of the coalition, but rather the fact that there is little alternation in power in Switzerland that accounts for low voter turnout. See Franklin, Voter Turnout and the Dynamics of Electoral Competition in Established Democracies Since 1945. 
indicating that voter participation is likely to increase when the margin of victory narrows between parties. Another contextual difference that appears to reduce voter participation is a country's level of democratization. Citizens in emerging democracies are less likely to vote than in older democracies. This finding is consistent with previous literature relying on aggregate data. ${ }^{61}$ Parties in newer democracies are likely to be poorly organized, poorly resourced and inexperienced in mobilization efforts and citizens report fewer contacts with political parties in emerging democracies. ${ }^{62}$ While we are unable to test this hypothesis directly, the lack of party organization in new democracies is likely to be a factor in explaining lower voter participation in these countries, particularly when one considers the results in Table 3, which indicate that democratization has no impact on efficacy.

While in the expected direction, the coefficient for the number of parties represented in parliament is just approaching statistical significance, suggesting that greater diversity in parliament may not be enough to boost voter participation. Compulsory voting more than triples the odds of voting. ${ }^{63}$ While disproportionality depresses efficacy, it fails to influence voter participation directly. ${ }^{64}$

Comparing the voter turnout and efficacy models, the individual and macro-level institutional variables help to explain more of the variance in voter participation than in efficacy across the twenty-seven countries in our sample. Moreover, the macro-level variables help to explain more of the variance in voter participation than in efficacy. Specifically, the amount of variance is reduced by about a third in the voter participation model when macro-level variables are added to the individual-level model, while in the efficacy model the reduction in variance is less than 10 per cent. In the voter turnout model, while 43 per cent of the variance can be explained by individual level factors, the addition of the macro-level variables reduces the total variance in voter participation to 29 per cent. In comparison, the total variance in the individual-level model predicting efficacy is 0.70 compared to 0.61 when macro-level variables are added to the model.

The results discussed above illustrate how various characteristics of the electoral system can have a positive or negative influence on a citizen's likelihood of voting. However, many of these variables are not independent of one another. A country that adopts PR, for example, will reduce disproportionality, which will improve efficacy. But in adopting PR, it will make coalition government more likely, which will have a negative effect. To estimate the full impact of the electoral system, we report predicted probabilities of voting across a range of 'real world' examples. These estimates, which are derived from the model in Table 4 are reported in Table 5. In a 'British'-style system, with single-party government and few parties, an average citizen has a likelihood of voting of 0.65 . In a 'Dutch'-style system, with a proportional system, broad coalitions and many parties, the probability of an average citizen voting with the same level of efficacy is 0.63 . If, as in Norway's case, PR is combined with single-party government, the likelihood of voting increases more to 0.76. Compulsory voting can also partly compensate for the negative effects of broad

${ }^{61}$ Norris, Electoral Engineering.

62 Sarah Birch, 'Single-member District Electoral Systems and Democratic Transition', Electoral Studies, 24 (2005), 281-301; Jeffrey A. Karp and Susan A. Banducci, 'Party Mobilization and Political Participation in New and Old Democracies', Party Politics, 13 (2007), 217-34.

${ }^{63}$ The effect is lower when all of the countries with compulsory voting are considered together irrespective of how the law is enforced. When considered separately, the impact is greatest for Australia and Belgium, where the level of enforcement is viewed as being stricter than in Mexico.

${ }^{64} \mathrm{We}$ also examined whether candidate based or party list systems influenced efficacy. These factors were not significant. 
TABLE 5 Likelihood of Voting under Different Systems

\begin{tabular}{cccccc}
\hline \hline & $\begin{array}{c}\text { 'British' style: } \\
\text { single-party } \\
\text { government, } \\
\text { few parties, } \\
\text { old democracy }\end{array}$ & $\begin{array}{c}\text { coalition } \\
\text { government, } \\
\text { many parties, } \\
\text { new } \\
\text { democracy }\end{array}$ & $\begin{array}{c}\text { 'Dutch' style: } \\
\text { broad } \\
\text { coalitions, } \\
\text { many parties, } \\
\text { old democracy }\end{array}$ & $\begin{array}{c}\text { Norwegian' } \\
\text { style: } \\
\text { single-party } \\
\text { government, } \\
\text { many parties, }\end{array}$ & $\begin{array}{c}\text { 'Belgian' style: } \\
\text { broad } \\
\text { coalitions, } \\
\text { many parties, } \\
\text { old democracy, } \\
\text { compulsory } \\
\text { voting }\end{array}$ \\
\hline $\begin{array}{c}\text { Mean } \\
\begin{array}{c}\text { Efficacy } \\
\text { Low } \\
\text { High }\end{array}\end{array}$ & 0.65 & 0.46 & 0.63 & 0.76 & 0.87 \\
\hline \hline
\end{tabular}

Note: Estimates derived from Table 4. Items that vary are set at their mean values for each country 'style' (see Appendix Table A1). Party Preference is set at the residual category (large party) and female is set to 1 . All other variables are held constant at their mean values in the sample.

coalitions, as is evident in a 'Belgian'-style system where a citizen has a probability of voting of 0.87 . In a new democracy with coalition government, the likelihood of voting is substantially reduced. In a 'Korean'-style system, an average citizen has a likelihood of voting of 0.46 . The estimates in Table 5 also show how efficacy, which itself is influenced by the electoral system, can alter a citizen's probability of voting. While an average citizen in a 'Norwegian'-style system is expected to have a higher likelihood of voting than a citizen in a 'British'-style system, the expected increase from the 'British' to the 'Norwegian'-style system is not nearly as substantial as moving from low to high efficacy within any system. In the 'British' case, a citizen with a low level of efficacy has a likelihood of voting of just 0.52 as compared to 0.71 for a citizen with a high level of efficacy. These effects illustrate the relative importance of individual level factors, which have largely been ignored in cross-national studies of turnout as well as contextual factors. Proportionality enhances overall turnout and these effects appear to be psychological, by reducing the proportion of citizens who believe their vote makes little difference in elections.

\section{DISCUSSION}

While previous research has found that PR systems are often associated with higher turnout, the reliance on aggregate data has made it difficult to explain just why this is the case. Electoral rules are thought to influence political attitudes and behaviour by offering incentives or disincentives to vote. A common assumption in many cross-national aggregate studies of turnout is that some voters are discouraged from participating because their vote is less likely to make a difference in systems that distort the translation of votes into seats. Voting is assumed to be more 'satisfying' for more voters in PR systems than under plurality rules because fewer votes are wasted. Aside from providing more effective representation for small parties, PR is viewed as the most appropriate method for guaranteeing the direct representation of minorities. ${ }^{65}$

${ }^{65}$ Katz, Democracy and Elections. 
Our results provide support for the assumption that attitudes and behaviour are likely to be influenced by institutional arrangements. Recent studies that have relied on individual-level data have reached similar conclusions. For instance, devices such as direct democracy can encourage a greater sense of efficacy and possibly civic engagement. ${ }^{66}$ In an analysis of European elections that provides one of the few examples where individual-level data are used to examine turnout in a cross-national context, Franklin observes that electoral rules such as Sunday or postal voting and compulsory voting can play an important role in stimulating electoral participation. ${ }^{67}$

Although those preferring small parties have lower levels of efficacy than those with a preference for large parties, the differences between them are smaller in proportional systems. These findings are analogous to those of Anderson and Guillory who find that the losers are likely to be less dissatisfied in consensus systems than in plurality systems. ${ }^{68}$ It also complements recent evidence from New Zealand, where political minorities experienced a greater shift in efficacy and participation than other voters following a change from a plurality to a PR system. ${ }^{69}$

Aside from minimizing the differences between political minorities, proportional systems appear to enhance overall participation by fostering stronger party preferences. This result is consistent with expectations that catch-all parties, because they need to appeal to the broadest base of support, do not foster strong preferences. Given the strong relationship between strength of preferences and voting, the stronger preferences found in PR systems lead one to expect higher overall rates of turnout. The results also complement other cross-national research that concludes that the threat of ideologically extreme parties helps to strengthen partisan attachments. ${ }^{70}$ Our analysis also suggests that strong preferences appear to counter the psychological effects produced by the electoral system. This conclusion is not new, the strength of partisan attachments has been recognized as an important influence on participation since the earliest voting studies. ${ }^{71}$ Yet such individual level factors have largely been neglected in cross-national studies of turnout because of the lack of available data. Our analysis suggests that psychological factors measured at the individual level are also important determinants of electoral participation. More importantly, these factors can be influenced by institutional arrangements.

66 Shaun Bowler and Todd Donovan, 'Democracy, Institutions and Attitudes about Citizen Influence on Government', British Journal of Political Science, 32 (2002), 371-90; Bruno S. Frey, Marcel Kucher and Alois Stutzer. 'Outcome, Process and Power in Direct Democracy: New Econometric Results', Public Choice, 107 (2001), 271-93.

67 Van der Eijk and Franklin, Choosing Europe?; Franklin, 'Electoral Participation'. In other models not reported here we found no evidence that postal or Sunday voting influenced voter participation in the CSES sample.

${ }^{68}$ Anderson and Guillory, 'Political Institutions and Satisfaction with Democracy'. It is also possible that electoral outcomes can influence winners' and losers' sense of political efficacy. Although one might hypothesize that efficacy is partly influenced by whether one voted for a winner or loser, we should also expect the indicator to tap into more long-term feelings about the political system. See Susan A. Banducci and Jeffrey A. Karp, 'How Elections Change the Way Citizens View the Political System: Campaigns, Media Effects, and Electoral Outcomes in Comparative Perspective', British Journal of Political Science, 33 (2003), 443-67, p. 464. Thus these observed differences are most likely a consequence of long-term loss rather than being the result of the more immediate electoral outcome.

${ }^{69}$ Banducci, Donovan and Karp, 'Proportional Representation and Attitudes about Politics'; and 'The Impact of Proportional Representation on Turnout'.

${ }^{70}$ Bowler, Lanoue and Savoie, 'Electoral Systems, Party Competition, and Strength of Partisan Attachment'.

71 Campbell et al., The American Voter. 
Finally, our analysis provides a resolution to the disagreement in the cross-national turnout literature on the effects of multipartism. While some suggest multipartism discourages voter participation because voters have less say in the formation of governments, others suggest that multipartism encourages participation through the effects of greater competition and party mobilization. This disagreement has been difficult to resolve without measuring efficacy directly. We find that the number of parties represented in parliament has no influence on political efficacy and while positively associated with voter participation, the number of parties in parliament is not quite statistically significant. In contrast, there is more support for the assumption that broad coalition governments depress efficacy which can discourage voter participation. Such a finding suggests that while proportional systems may foster positive attitudes and behaviour, the formation of broad based power-sharing agreements could partly offset these advantages.

APPENDIX

TABLE A 1 Sample of Countries and their Institutional Characteristics

\begin{tabular}{|c|c|c|c|c|c|c|}
\hline Electoral system & Country & Disproportionality & Parties & $\begin{array}{l}\text { Coalition } \\
\text { size }\end{array}$ & $\begin{array}{l}\text { Compulsory } \\
\text { voting }\end{array}$ & $\begin{array}{c}\text { New } \\
\text { democracy }\end{array}$ \\
\hline \multirow[t]{15}{*}{ PR Systems } & $\begin{array}{l}\text { Belgium } \\
\text { Czech }\end{array}$ & 4.6 & 9 & 6 & Yes & No \\
\hline & Republic & 4.4 & 6 & 2 & No & Yes \\
\hline & Denmark & 0.7 & 10 & 2 & No & No \\
\hline & Finland & 3.0 & 5 & 3 & No & No \\
\hline & Iceland & 2.0 & 5 & 2 & No & No \\
\hline & Ireland & 6.4 & 7 & 2 & No & No \\
\hline & Israel & 1.7 & 10 & 2 & No & No \\
\hline & Netherlands & 1.1 & 6 & 3 & No & No \\
\hline & Norway & 3.7 & 7 & 1 & No & No \\
\hline & Poland & 9.8 & 4 & 1 & No & Yes \\
\hline & Portugal & 5.4 & 5 & 2 & No & No \\
\hline & Slovenia & 2.6 & 7 & 2 & No & Yes \\
\hline & Spain & 5.5 & 4 & 1 & No & No \\
\hline & Sweden & 1.0 & 7 & 1 & No & No \\
\hline & Switzerland & 2.7 & 6 & 4 & No $\dagger$ & No \\
\hline \multirow[t]{4}{*}{ MMP Systems } & Germany & 2.6 & 6 & 2 & No & No \\
\hline & Mexico & 7.1 & 3 & 1 & Yes & Yes \\
\hline & New & & & & & \\
\hline & Zealand & 2.9 & 5 & 1 & No & No \\
\hline \multirow[t]{5}{*}{ Mixed Systems } & Hungary & 8.4 & 6 & 1 & No & Yes \\
\hline & Japan & 8.8 & 5 & 3 & No & \\
\hline & Korea & 8.8 & 4 & 2 & No & Yes \\
\hline & Russia & 5.5 & 9 & 2 & No & Yes \\
\hline & Ukraine & 2.4 & 10 & 1 & No & Yes \\
\hline \multirow[t]{4}{*}{ Plurality Systems } & Canada & 13.3 & 5 & 1 & No & No \\
\hline & United & & & & & \\
\hline & Kingdom & 16.8 & 3 & 1 & No & No \\
\hline & $\begin{array}{l}\text { United } \\
\text { States }\end{array}$ & 4.2 & 2 & 2 & No & No \\
\hline Majority Systems & Australia & 10.2 & 3 & 2 & Yes & No \\
\hline
\end{tabular}

$\dagger$ In Switzerland, compulsory voting is used only in the canton of Schaffhausen. 
TABLE A 2 Coding for Large and Small Party Preference

\begin{tabular}{|c|c|c|}
\hline Country & Large Parties & Small Parties \\
\hline Australia & Liberal, Australian Labor & $\begin{array}{l}\text { National (Country), Australian Democrats, } \\
\text { Greens }\end{array}$ \\
\hline Belgium & None & All parties in Wallonia and Flanders \\
\hline Canada & Liberal & $\begin{array}{l}\text { Progressive Conservative, NDP, Reform, Bloc } \\
\text { Quebecois }\end{array}$ \\
\hline $\begin{array}{l}\text { Czech } \\
\text { Republic }\end{array}$ & CSSD, ODS & KDU-CSL, KSCM, ODA, SPR-RSC \\
\hline Denmark & $\begin{array}{l}\text { Social Democrat (SD), } \\
\text { Liberal Party (V) }\end{array}$ & $\begin{array}{l}\text { Conservative (KF), Centre Democrat (CD), } \\
\text { Socialist People (SF), Danish People (DF) }\end{array}$ \\
\hline Finland & $\begin{array}{l}\text { Social Democrat, Centre } \\
\text { Party }\end{array}$ & $\begin{array}{l}\text { National Coalition, Left Alliance, Swedish } \\
\text { People's Party, Christian Democrats, Green } \\
\text { League }\end{array}$ \\
\hline Germany & CDU, SPD & CSU, FDP, Greens, PDS, Republikaner, DVU \\
\hline Hungary & Fidesz-MPP, MSZP & $\begin{array}{l}\text { FKGP, MDF, MIEP, SZDSZ, Munkaspart, } \\
\text { MDNP }\end{array}$ \\
\hline Iceland & Alliance, Independence & Progressive, Left Greens, Liberal \\
\hline Ireland & Fianna Fail, Fine Gael & $\begin{array}{l}\text { Green, Labour, Progressive Democrats, Sinn } \\
\text { Fein }\end{array}$ \\
\hline Israel & Likud, Avoda & Shas, Mafdal, Meretz, Tzomet \\
\hline Japan & $\begin{array}{l}\text { Liberal Democratic Party, } \\
\text { New Frontier Party }\end{array}$ & $\begin{array}{l}\text { Democratic Party of Japan, Social Democratic } \\
\text { Party, Japan Communist Party, New Party } \\
\text { Harbinger, New Socialist Party, FreeDom } \\
\text { Union }\end{array}$ \\
\hline Korea & $\begin{array}{l}\text { Grand National Party, } \\
\text { Millenium Democratic } \\
\text { Party }\end{array}$ & $\begin{array}{l}\text { United Liberal Democrats, Democratic } \\
\text { Peoples Party, New Korean Party of the Hope, } \\
\text { Democratic Liberal Party }\end{array}$ \\
\hline Mexico & PAN, PRI, PRD & PT, PVEM, PC, PPS, PDM \\
\hline Netherlands & $\begin{array}{l}\text { Labour (PvdA), People's } \\
\text { Party for Freedom and } \\
\text { Democracy (VVD) }\end{array}$ & $\begin{array}{l}\text { Christian Democratic Appeal (CDA), D66, } \\
\text { GroenLinks, SGP, GPV, RPF }\end{array}$ \\
\hline New Zealand & National, Labour & $\begin{array}{l}\text { Act, Alliance, New Zealand First, Christian } \\
\text { Coalition }\end{array}$ \\
\hline Norway & Labour Party & $\begin{array}{l}\text { Christian People's Party, Center Party, } \\
\text { Socialist Left Party, Conservative Party, } \\
\text { Progress Party }\end{array}$ \\
\hline Poland & $\begin{array}{l}\text { Solidarity Election Action, } \\
\text { Democratic Left Alliance }\end{array}$ & $\begin{array}{l}\text { Movement for the Reconstruction of Poland, } \\
\text { Polish Peasant Party, Freedom Union, Union } \\
\text { of Labour }\end{array}$ \\
\hline Portugal & $\begin{array}{l}\text { Social Democratic Party, } \\
\text { Socialist Party }\end{array}$ & $\begin{array}{l}\text { Popular Party, Unitary Democratic Coalition, } \\
\text { Left Block, Portuguese Communist Workers' } \\
\text { Party }\end{array}$ \\
\hline Russia & $\begin{array}{l}\text { Communist Party of the } \\
\text { Russian Federation, } \\
\text { Yedinstvo (Unity) }\end{array}$ & $\begin{array}{l}\text { Fatherland All Russia, Union of Right Forces, } \\
\text { Yabloko }\end{array}$ \\
\hline
\end{tabular}


TABLE A2 (Continued)

\begin{tabular}{|c|c|c|}
\hline Country & Large Parties & Small Parties \\
\hline Slovenia & $\begin{array}{l}\text { Liberal Democratic Party } \\
\text { (LDS) }\end{array}$ & $\begin{array}{l}\text { Slovenian People's Party (NSi), Social } \\
\text { Democratic Party (SDSS), Christian } \\
\text { Democrats (NSi), United List of Social } \\
\text { Democrats (ZLSD), Democratic Party of } \\
\text { Retired Persons (DeSUS) }\end{array}$ \\
\hline Spain & $\begin{array}{l}\text { People's Party (PP), } \\
\text { Socialist Party (PSOE) }\end{array}$ & $\begin{array}{l}\text { CDS, United Left (IU), Convergence \& Unity } \\
\text { (CiU), Basque Nationalist Party (PNV) }\end{array}$ \\
\hline Sweden & $\begin{array}{l}\text { Sweden's Social } \\
\text { Democratic Worker's Party } \\
\text { (SAP), Moderate Rally } \\
\text { Party (M), }\end{array}$ & $\begin{array}{l}\text { Left Party (Vp), Centre Party (C), People } \\
\text { Party's Liberals (Fpl), Christian Democrats } \\
\text { (KD) }\end{array}$ \\
\hline Switzerland & $\begin{array}{l}\text { Swiss People's Party } \\
\text { (SPS), Social Democrat } \\
\text { (SPS), Free Thinking }\end{array}$ & Green Party (GPS) \\
\hline Ukraine & $\begin{array}{l}\text { Communist Party of } \\
\text { Ukraine }\end{array}$ & $\begin{array}{l}\text { People's Rukh of Ukraine, Socialist Party of } \\
\text { Ukraine, Social-Democratic Party, } \\
\text { People's-Democratic Party }\end{array}$ \\
\hline $\begin{array}{l}\text { United } \\
\text { Kingdom }\end{array}$ & Conservative, Labour & $\begin{array}{l}\text { Liberal Democrats, Scottish National Party, } \\
\text { Plaid Cymru }\end{array}$ \\
\hline United States & Democrat, Republican & Reform Party \\
\hline
\end{tabular}

Note: Interviewers were instructed to ask about all parties likely to be represented in parliament. In circumstances where there were more than six parties, interviewers were instructed to ask about the six most relevant parties. 